\title{
THE EFFECT OF INVESTMENT, CAPITAL EXPENDITURE, AND DISTRICT / CITY MINIMUM WAGE ON INCLUSIVE ECONOMIC DEVELOPMENT IN THE REGENCY / CITY OF BALI PROVINCE, INDONESIA
}

\author{
Mahaendrayasa Made Sinthya Aryasthini, Budhi Made Kembar Sri \\ Faculty of Economics and Business, Udayana University, Bali, Indonesia \\ ${ }^{\star}$ E-mail: mdsinthyaaryasthinim@gmail.com
}

\begin{abstract}
The achievement of equitable community welfare is one of the goals expected by every district/city including in the Province of Bali. There are various factors that can affect community welfare and inclusive economic development, such as: life expectancy, health, school enrollment rates, minimum wages, percentage of population poor, investment, and the allocation of financing from the government for public facilities. The data used is secondary data, namely district/city panel data in the Province of Bali in 2015-2019 which was obtained from the Central Statistics Agency for the Province of Bali and Bappenas. The data is analyzed using path analysis. The results show that direct investment has a positive and significant impact on people's welfare. The district/city minimum wage has a direct positive and significant effect on inclusive economic development and community welfare in the districts/cities of Bali Province. Investment has a positive and insignificant effect on inclusive economic development. Capital expenditure has a negative and significant effect on inclusive economic development and community welfare. Inclusive economic development has a direct positive and insignificant effect on the welfare of the people in the districts/cities of Bali Province. Inclusive economic development as an intervening variable is only on capital expenditure on people's welfare.
\end{abstract}

\section{KEY WORDS}

Capital expenditure, community welfare, inclusive economic development, investment, minimum wages.

The achievement of equitable community welfare is one of the goals expected by every region, including regencies/cities in the province of Bali. According to Mosher (1987), the most important thing to achieve prosperity is to obtain sufficient income to meet needs, because some aspects of household welfare depend on the level of income. There are various factors that can affect people's welfare, such as: life expectancy, health, school enrolment rates, minimum wages, percentage of poor people, investment, and the allocation of funding from the government for public facilities (Gustyarini, 2019).

The local potential that varies from one region to another causes the focus of development in each region to be different. Local potential owned can be in the form of potential resources derived from nature, human resources, and regional potential that can be used as a source of regional income to meet the financing needs of regional governments and also regional development through accurate allocations as needed. The realization of Good Governance, by involving the community and the private sector as partners in the implementation of development and transparency in the field of government will maintain the achievement of the human development index in all areas of the Province of Bali (Rustariyuni, 2012). One of the benchmarks used to measure the quality of human life is the Human Development Index (HDI), which is measured through the quality of education, health and economic levels (purchasing power). Through the improvement of these three indicators, it is hoped that there will be an increase in the quality of human life (Anggatia, 2012).

The pattern of government that is carried out not based on the needs of the community can lead to a decrease in the number of people's welfare which can be monitored by looking at the level of the Human Development Index (HDI). Based on Table 1.1, it can be seen that there has been an increase in the HDI figures for districts/cities in Bali Province. Although the 
HDI figures tend to increase, the growth of the district/city HDI in the Province of Bali still fluctuates during the 2015-2019 period, the average HDI growth tends to be low, which is below 1 point. Karangasem Regency with an HDI achievement of 65.86 points is the district with the lowest average HDI achievement for the last five years 2015-2019. The highest average HDI in the last five years 2015-2019 was achieved by the city of Denpasar with an achievement of 82.96 points.

Table 1 - District/City Human Development Index Level in Bali Province 2015-2019 (Points)

\begin{tabular}{lllllll}
\hline \multirow{2}{*}{ District/City } & \multicolumn{7}{l}{ Human Development Index } & \multirow{2}{*}{ Rata-rata } \\
\cline { 2 - 5 } & 2015 & 2016 & 2017 & 2018 & 2019 & 70,95 \\
Jembrana & 69,66 & 70,38 & 70,72 & 71,65 & 72,35 & 74,84 \\
Tabanan & 73,54 & 74,19 & 74,86 & 75,45 & 76,16 & 80,33 \\
Badung & 78,86 & 79,80 & 80,54 & 80,87 & 81,59 & 76,11 \\
Gianyar & 75,03 & 75,70 & 76,09 & 76,61 & 77,14 & 70,20 \\
Klungkung & 68,98 & 69,31 & 70,13 & 70,90 & 71,71 & 67,96 \\
Bangli & 66,24 & 67,03 & 68,24 & 68,96 & 69,35 & 65,86 \\
Karangasem & 64,68 & 65,23 & 65,57 & 66,49 & 67,34 & 71,15 \\
Buleleng & 70,03 & 70,65 & 71,11 & 71,70 & 72,30 & 82,96 \\
Denpasar & 82,24 & 82,58 & 83,01 & 83,30 & 83,68 & 74,27 \\
\hline Bali Province & 73,27 & 73,65 & 74,30 & 74,77 & 75,38 & \\
\hline
\end{tabular}

Source: Central Bureau of Statistics of Bali Province, 2020.

This shows that there is still inequality in HDI achievement among districts/cities in Bali Province, due to differences in the quality of human resources as well as infrastructure in the fields of education, health and income per capita as an HDI indicator (Astri, 2013).

Tourism is the leading sector in Bali Province which is a source of economic growth (Putra, 2018). However, this sector is more focused on the South Bali area, so that various developments related to supporting facilities are given to areas located in South Bali such as Badung Regency and Denpasar City. This causes development imbalances in some areas that are not tourism centers as well as economic and government centers which cause differences in the achievements of people's welfare in each region (Luthfiyah and Amandus, 2020). Various efforts are designed and implemented by local governments solely to improve various indicators of economic development for the region itself and are then expected to have a positive impact on the welfare of its people (Ehrenberg, 2009). One of the efforts made by local governments in achieving their goals is to implement inclusive economic development (Kaur, 2016). Inclusive economic development contains three main pillars, namely high economic growth; income distribution and poverty reduction; and expansion of access and opportunities to improve people's welfare (Widyasanti, 2020). Inclusive economic development in the regions is expected to be able to overcome ongoing problems such as reducing poverty levels, unemployment rates, very low education and other inequalities between districts/cities, so as to improve people's living standards (Artana, 2017).

According to Bappenas (2020), Bali Province is the second most inclusive province in Indonesia in 2019 and is in the second highest ranking after DKI Jakarta with an inclusive economic development index of 6.77 points. There is a disparity in inclusive economic development index achievement in the districts/cities of Bali Province with Denpasar City having the highest inclusive economic development index achievement with 6.37 points. Karangasem Regency is the district with the lowest inclusive economic development index achievement with 5.69. With an average inclusive economic development index achievement of 5.9 points, Bali Province provides a limit that there are still regencies in Bali Province whose achievements are below the average inclusive economic development index achievement of Bali, including Jembrana, Tabanan, Bangli, Buleleng, and Karangasem Regencies. Inequality and gaps that occur are caused by human resources, demographic changes, unemployment, and migration, so that people's welfare becomes uneven (Abdullah, 2011).

In the development of a region, the need for the region to spend a number of relatively large costs tends to open up opportunities for cooperation with investors from outside the 
government. The cooperation can be in the form of investment in the form of Foreign Investment/FI and Domestic Investment/DI (Ali, 2013). Equitable distribution of investment in Bali Province is expected to be able to create the realization of inclusive economic development in all districts/cities in Bali (Ka'arieni, 2020). In fact, the realization of investment in Bali Province is still uneven, because in several districts such as Bangli Regency, Gianyar Regency, and Klungkung Regency which still have not received attention from investors compared to Badung Regency or Denpasar City (Putri, 2017). The realization of incoming investment, both from Foreign Investment (FI) and Domestic Investment (DI), has a wide disparity. The average investment from the 2019 period in eight regencies and one city in Bali Province was IDR 1,532 billion. The highest average investment gain from 2015-2019 was in Denpasar City with an investment gain of IDR 5,890 billion and the lowest average investment from 2015-2019 was in Bangli Regency with an investment gain of IDR 33 billion. The condition of the uneven distribution of investment in the districts/cities of the Bali Province has resulted in the uneven distribution of regional inclusive economic development, which in turn has an impact on the disparity in the achievement of community welfare in the districts/cities of Bali Province (Krismajaya, 2019).

According to Mehrara (2011), government spending can be used as an indicator of the size of government activities, because all government activities always require financing. The increasing role of the government can be seen from the increasing size of government spending in proportion to GRDP (Ari, 2014). Policies in the government budget are important for changing development to reduce inequality in a region, so that the target of inclusive economic development can be achieved which will indirectly have an impact on improving people's welfare. Fasoranti (2012), stated that to be able to increase inclusive economic development, the government must be able to control its direct expenditure. An increase in routine spending will only have an impact on higher inequality, because only certain groups enjoy it, but on the contrary if development spending has a larger proportion it will have a direct effect on inclusive economic development and on people's welfare (Ehrenberg, 2009).

Local government capital expenditures directly or indirectly have a role in triggering growth in an area (Salih, 2012). Capital expenditures are productive and in direct contact with the public interest so that they are able to provide economic stimulus (Syametal, 2018). For the Province of Bali, the difference in regional income causes the total allocation of capital expenditure in each district/city to be different which causes differences in the achievements of inclusive economic development which causes differences in the achievements of community welfare in each district/city. Every year, the capital expenditure of Bali Province fluctuates and tends to decrease in 2018 to 2019. The average realization of capital expenditure in eight districts and one city in Bali Province in 2019 was IDR 276 billion with the highest realization of capital expenditure in Badung Regency. with the realization of capital expenditure of IDR 825 billion, and Klungkung Regency as the district with the lowest realization of capital expenditure with realization of IDR 129 billion.

The wage level factor is very important to support inclusive economic development (Bozena, 2016). With the improvement in wages, there will be an increase in workers' income and people's purchasing power which will have an impact on increasing the level of community welfare (Atkinson and Laventi, 2017). Increasing people's purchasing power will be a stimulus in economic development in an area (Eldy, 2016). The highest regency/city minimum wage is set in Badung Regency at IDR 2.7 million and the lowest is IDR 2.3 million in Klungkung Regency.

There is a link between investment, capital expenditure, and district/city minimum wages on inclusive economic development and community welfare, causing the need for cooperation between the government, investors, and the community. Good cooperation is expected in the management of funds in economic activities, both investment, capital expenditure, and district/city minimum wages in order to increase the achievement of inclusive economic development (Miranti, 2014). The role of the government is very large in efforts to achieve inclusive economic development through financing issued by the government (Isa et al, 2019), so that the next hope is to be able to improve the achievement of community welfare in Bali Province (dalamagas et al, 2010). 


\section{LITERATURE REVIEW}

The general requirement for economic development in a country according to Todaro (2010) is a successful accumulation of capital if the proportion of existing income is saved and invested to increase product (output) and income in the future. To realize this, the government needs to divert spending from consumption flows to investment in the form of "capital formation" to achieve a higher level of production. Investments in various sectors will be able to accelerate development and ultimately increase the level of community welfare (Brata, 2005). According to Harrod-Domar Theory in Rahmawati (2015), it is necessary to create a climate that can stimulate investment, especially private investment that is able to create employment opportunities, so that it can increase job opportunities which have an impact on increasing the inclusive economic development index and will also increase the achievement of community welfare.

According to Akudugu (2012), an increase in capital expenditure will contribute to improving people's welfare, if capital expenditure is used to build and improve infrastructure for public pulDRoses (Awandari, 2016). This will create access and opportunities that will have an impact on increasing inclusive economic development index achievements and also have an impact on improving people's welfare.

The wage system is a framework for how wages are regulated and determined in order to improve the welfare of workers. If the wages received are more in line with the necessities of life, the needs for clothing, food and shelter will be fulfilled, so that welfare will be better (Eldy et al, 2016). Bappenas (2017) defines inclusive economic development as economic growth that creates broad access and opportunities for all levels of society in an equitable manner, improves welfare, and reduces disparities between groups and regions. Inclusive economic development policies supported by stakeholders are able to create business opportunities, increase incomes, and equitable and comprehensive community welfare.

According to Mosher (1987), the most important thing about welfare is income, because some aspects of household welfare depend on the level of income. Fulfillment of needs is limited by household income, especially for those with low incomes. The higher the household income, the lower the percentage of income for food.

\section{METHODS OF RESEARCH}

This research is an associative quantitative research. Collecting data by means of non-participant observation, using secondary data obtained from Bappenas, BPS Bali Province, and the Office of Investment and One Stop Integrated Services, and other supporting institutions. This study uses panel data with data used are investment data, capital expenditures, regency/city minimum wage, inclusive economic development index, and HDI in nine regencies/cities of Bali Province from 2015-2019, so the number of samples to be studied is 45 observation points. The data analysis technique used path analysis.

\section{RESULTS AND DISCUSSION}

Based on the results of data processing, the direct effect of a variable on other variables in this study is concluded in Table 2.

Table 2 - Direct Effects of Research Variables

\begin{tabular}{|c|c|c|c|c|c|}
\hline Regresi & Coefficient & Std Error & T-statistic & Prob. & Information \\
\hline $\mathrm{X}_{1}->\mathrm{Y}_{1}$ & 0.001418 & 0.000931 & 1.524149 & 0.1370 & Positive and insignificant \\
\hline$X_{2}->Y_{1}$ & -0.022851 & 0.013713 & -1.666418 & 0.1051 & Negative and insignificant \\
\hline$X_{3}->Y_{1}$ & 0.269330 & 0.035539 & 7.578359 & 0.0000 & Positive and significant influence \\
\hline$X_{1} \rightarrow Y_{2}$ & 0.008429 & 0.003308 & 2.548012 & 0.0158 & Positive and significant influence \\
\hline$X_{2} \rightarrow Y_{2}$ & -0.031207 & 0.049064 & -0.636050 & 0.5293 & Negative and insignificant \\
\hline$X_{3}->Y_{2}$ & 3.059520 & 0.202163 & 15.13395 & 0.0000 & Positive and significant influence \\
\hline$Y_{1} \rightarrow Y_{2}$ & 0.593941 & 0.598179 & 0.992915 & 0.3282 & Positive and insignificant \\
\hline
\end{tabular}

Note: X1 - Investment; X2 - Capital expenditure; X3 - Regency/city minimum wage; Y1 - Inclusive economic development; Y2 - Community welfare. 
Based on Table 2, it can be explained that there are three relationships that have a positive and significant effect on the influence between research variables, including:

1. The effect of the district/city minimum wage on inclusive economic development, the results of the data test show the beta coefficients value of 0.269330 with a significance of $0.0000<0.05$, then $\mathrm{H} 0$ is rejected and $\mathrm{H} 1$ is accepted, which means The district/city minimum wage has a direct positive and significant effect on inclusive economic development in the districts/cities of Bali Province. Wage theory states that higher wages can increase incentives for people to work harder and thus higher wages can increase labor productivity (Simona Ferraro, 2018). Wage levels are very important and strategic in nature to support development in an area (Gindling, 2018). The improvement in the minimum wage standard in the districts/cities of Bali Province has caused the purchasing power of workers to increase and lead to an increase in household consumption which encourages income distribution. The increase in workers' income and people's purchasing power will cause the real sector to develop, which in turn will encourage economic growth, income distribution and poverty reduction as well as the expansion of public access and opportunities to enjoy public services and facilities, so that the increasing target of inclusive economic development can be realized as a whole. in the regency/city of Bali Province.

2. The effect of investment on people's welfare, the results of data testing show the beta coefficients value of 0.008429 with a significance of $0.0158<0.05$, then $\mathrm{HO}$ is rejected $\mathrm{H} 1$ is accepted, thus investment directly has a positive and significant impact on the welfare of the people in the district / city of Bali Province. Although the investment allocation is not evenly distributed in every district/city in Bali Province, investment has been able to provide a stimulus to the level of education, life expectancy and per capita income. at least 20 percent and 10 percent of the APBD in all regions, so that the welfare of the people in the regencies/cities of the Province of Bali increases. Investment allocation that is more evenly distributed between regions will be able to further encourage the achievement of community welfare in the districts/cities of Bali Province. According to Tandelilin (2010), there are several reasons why someone invests, one of which is to get a more decent life in the future. When people's incomes increase, access to health and education which is a component of community welfare can be achieved (Ramirez et al, 2015).

3. The effect of the district/city minimum wage on the welfare of the community, the results of the data test show the beta coefficients value of 3.059520 with a significance of $0.0000<0.05$, then $\mathrm{H} 0$ is rejected and $\mathrm{H} 1$ is accepted, which means the district/city minimum wage City directly has a positive and significant impact on the welfare of the people in the regency/city of Bali Province. According to the Law of the Republic of Indonesia Number 13 of 2003 concerning Manpower, in Chapter I Article 1 number 30 it is explained Wages are the rights of workers/laborers received and expressed in the form of money as compensation from the entrepreneur or employer to workers/laborers who are determined and paid according to a work agreement, agreement, or legislation, including allowances for workers/laborers and their families, for a job or service that has been or will be performed (Nashahta Ardhianty, 2018). The improvement in the minimum wage standard in the districts/cities of Bali Province has caused the purchasing power of workers to increase and lead to an increase in household consumption which encourages income distribution. According to Vicente and Aniceto (2016), an increase in the level of welfare can be seen from the ability to obtain basic needs that are easier, can enjoy paid health and education facilities, so that a decent quality of life for the community can be achieved.

Two relationships that have a positive and insignificant effect, among others.

1. The effect of investment on inclusive economic development, the test results show the beta coefficients value of 0.001418 with a significance of $0.1370>0.05$, then $\mathrm{H} 0$ is accepted and $\mathrm{H} 1$ is rejected, this means that investment has a direct positive effect and not significant to inclusive economic development in districts/cities of Bali 
Province. Harrod-Domar theory in Arsyad (2010) views that capital formation is considered as an expenditure that will increase the ability of an economy to produce goods and or services, as well as an expenditure that will increase the effective demand of the whole community. If at a certain period a certain amount of capital formation is carried out, then in the next period the economy has the ability to produce greater goods and or services, so that investment is evenly distributed in each district/city, it is hoped that investment will be able to provide a development stimulus in all regions. so that it will be able to expand employment so that more people can be absorbed in it, thus people's income can increase. When people's incomes increase through the multiplier effect, the overall development targets in various sectors will be achieved. However, in reality, the diversity of regional potential advantages has not been followed by an even allocation of investment to all districts/cities of Bali Province. The incoming investment is more centered in the SARBAGITA area because of the potential of the region with the tourism sector which is considered superior and more promising by investors, while there are still other superior sectors such as the agricultural sector in a broad sense which is no less promising.

2. The effect of inclusive economic development on people's welfare, the results of the data test show the beta coefficients value of 0.593941 with a significance of 0.3282 > 0.05 then $\mathrm{HO}$ is accepted, which means that inclusive economic development directly has a positive effect and not significant to the welfare of the people in the regency/city of Bali Province. Inclusive economic development in regencies/cities of Bali Province is not optimal, because it is still not optimal in managing investment and capital expenditures in each regency/city of Bali Province. Investments and capital expenditures that are not managed properly will not be able to optimally encourage economic growth, encourage income distribution and poverty reduction and expand access and opportunities for the community to enjoy public services and facilities, so that they are not optimal in promoting community welfare (Isa et al, 2019).

Two relationships that have a negative and insignificant effect, including.

1. The effect of capital expenditure on inclusive economic development, the results of the data test show the beta coefficients value of -0.022851 with a significance of $0.1051>0.05$, then $\mathrm{H} 0$ is accepted, thus capital expenditure has a direct negative effect and does not significant impact on inclusive economic development in the districts/cities of Bali Province. The basic capital for carrying out economic activities in an area is the availability of infrastructure facilities and infrastructure to support economic activities, so that the development of economic infrastructure can be a trigger for inclusive economic development, namely the allocation of targeted expenditure budgets. The link between capital expenditure and inclusive economic development is that the expenditure made by the government, especially in the realization of capital expenditure is used to support comprehensive economic development, so that it can stimulate economic growth, reduce inequality, alleviate poverty and expand access and opportunities for the community, provided that capital expenditure is used properly targeted according to the potential and development targets in each region. However, in reality, the construction of infrastructure facilities and infrastructure in all regions has not been properly studied, especially in terms of location, regional needs and community participation. The benefits of infrastructure facilities and infrastructure will be optimal, if the location is right, it is very much needed by the local area and aspirations arise from below through broad community participation (bottom up). Many examples of abandoned public facilities are underutilized or not used according to their designation, because the location is not right or not/not needed by the local community.

2. The effect of capital expenditures on people's welfare, the test results show that the beta coefficients value is -0.031207 with a significance of $0.5293>0.05$, then $\mathrm{HO}$ is accepted, thus capital expenditures directly have a negative and insignificant effect on people's welfare in the regency/city of Bali Province. These results can be 
interpreted that the high HDI figure is a reflection of the increase in people's welfare which can be achieved through increased realization of local government capital expenditures as providers of educational, health and economic facilities if properly allocated. With the existence of capital expenditures from the government, it can realize community welfare with better quality human resources (Isa et al, 2019). However, by looking at the negative results on the relationship of the effect of capital expenditure on the welfare of the people in the regency/city of Bali Province, it means that the development of infrastructure facilities and infrastructure financed by the capital expenditure budget for all regions has not been able to improve the welfare of the community. There is a tendency for local governments to use capital expenditure budgets for activities that are physical or infrastructure development, so that the absorption of labor is lower which has an impact on the decline in community welfare, while the benefits of providing infrastructure facilities and infrastructure are also not optimal for the wider community to enjoy due to the availability of infrastructure. is not evenly distributed and does not meet the needs.

The indirect effect of a variable on other variables in this study is presented in Table 3 and was tested using the Sobel test.

Table 3 - Indirect Effect of Research Variables

\begin{tabular}{lllll}
\hline Relations & Mediating Variable & Value & $Z$ & Information \\
\hline$X_{1} \rightarrow Y_{2}$ & $Y_{1}$ & 0,0010 & 0,83 & Not significant \\
$X_{2} \rightarrow Y_{2}$ & $Y_{1}$ & 0,0159 & $-0,85$ & Significant \\
$X_{3}>Y_{2}$ & $Y_{1}$ & 0,1624 & 0,98 & Not significant \\
\hline
\end{tabular}

Note: X1 - Investment; X2 - Capital Expenditure; X3 - Regency/city Minimum Wage; Y1 - Inclusive Economic Development; Y2 - Community Welfare.

Based on Table 3, the results of the data test show that $Z$ count of investment variables, capital expenditures, and district/city minimum wages on community welfare through inclusive economic development, only one is worth more than 1.96, namely capital expenditure. This means that investment and district/city minimum wages indirectly have no significant effect on community welfare through inclusive economic development, in contrast to capital expenditures which show that capital expenditures indirectly have a significant impact on people's welfare through development. inclusive economy in the districts/cities of Bali Province.

\section{CONCLUSION}

The results of the analysis show that direct investment has a positive and significant impact on people's welfare. The district/city minimum wage directly has a positive and significant effect on inclusive economic development and community welfare in the districts/cities of Bali Province. Investment has a positive and insignificant effect on inclusive economic development. Capital expenditures have a negative and significant effect on inclusive economic development and community welfare. Inclusive economic development has a direct positive and insignificant effect on the welfare of the people in the districts/cities of Bali Province. Inclusive economic development as an intervening variable is only on capital expenditures on people's welfare.

The suggestions put forward are as follows. Local governments are expected to create a more conducive investment climate as a stimulus for equal distribution of investment between regions and the incoming investment should be used to increase the distribution of more inclusive economic development through various development activities that use more human labor (labor intensive) compared to capital or machines. capital intensive). Given the limited budget, local governments should be careful in determining the allocation of capital expenditures based on a priority scale, absorbing bottom-up aspirations, especially with regard to the needs and the exact location of infrastructure provision in the regions. In order to improve the welfare of workers, there is a need for a strong commitment from the owners 
of business entities that use labor to treat workers properly by providing workers' rights such as wages with a minimum amount in accordance with the regulations set by the regional government regarding wage setting standards, so that the necessities of life are decent. Workforce can be fulfilled, thereby encouraging the creation of inclusive economic development that leads to better community welfare in the districts/cities of Bali Province..

\section{REFERENCES}

1. Abdullah, Burhanuddin, 2011. Manajemen Sumber Daya Manusia Perusahaan. Jakarta: PT. Raja Grafindo Persada.

2. Akonji, D. A., Olubukola, O. A., and Wakilia, A. M. 2013. Nexus Between Publik Expenditure and Economic Growth By Testing Wagner's Law Time Series: Evidence From Nigeria. International Journal of Development and Sustainability. 2(4). Hal: 23832395.

3. Akudugu, Jonas Ayaribilla. 2012. Accountabillity in local Government revenue management: who does what?. Journal of Sustainable Development. 2(8). Hal: 22-32.

4. Ali, Hasnah, Er, A.C., Ahmad, A.R., Lyndon, N., Ahmad, Sanep. 2013. Analysis of the Impact of Foreign Investment on Regional Disparities: A Case of Malaysia. Asian Sosial Science. 9(14). Halaman: 209-218.

5. Anggatia, ariza. 2014. Pengaruh Pertumbuhan Ekonomi dan Belanja Modal Terhadap Indeks Pembangunan Manusia (IPM) Dalam perspektif Islam. Jurnal Ekonomi Pembangunan. Universitas Islam.

6. Ari Surya Permana, I Gusti Agung Bagus. 2014. Jurnal. Pengaruh Produk Domestik Regional Bruto (PDRB) dan Tingkat Upah Terhadap Kesempatan Kerja melalui Investasi Di Provinsi Bali Tahun 1993-2013.E-Jurnal Ekonomi Pembangunan Universitas Udayana, 4(4) hal: $230-242$.

7. Arini, Prima Rosita. 2016. Pengaruh Belanja Modal Terhadap Pertumbuhan Ekonomi dan Kesejahteraan Masyarakat di Pulau Kalimantan. JRAMB. Vol. 2 No.2. ISSN: 2460-1233.

8. Artana Yasa, I Komang Oka; Arka, Sudarsana. 2017. Pengaruh Pertumbuhan Ekonomi dan Disparitas Pendapatan Antardaerah Terhadap Kesejahteraan Masyarakat Provinsi Bali. Jurnal Ekonomi Kuantitatif Terapan, [S.I.], nov. 2015. ISSN 2303-0186. Available at:. Date accessed: 28 Nov. 2020. Vol. 8, No. 1, pp: 1-112.

9. Astri Meylina, Sri Indah Nikensari, dan Harya Kuncara, 2013. Pengaruh Pengeluaran Pemerintah Daerah pada Sektor Pendidikan dan Kesehatan Terhadap Indeks Pembangunan Manusia di Indonesia. Jurnal Pendidikan Ekonomi dan Bisnis. 1(1): h: 77102.

10. Atkinson \& Leventi. 2017. Reducing poverty and inequality through tax-benefit reform and the minimum wage: the UK as a case-study. Journal Econ Inequel. Volume 10 Issue 1. 375-395.

11. Awandari, Luh Putu Putri dan I Gst Bgs Indrajaya. 2016. Pengaruh Infrastruktur, Investasi dan Pertumbuhan terhadap Kesejahteraan Masyarakat Melalui Kesempatan Kerja. EJurnal Ekonomi Pembangunan. Universitas Udayana. ISSN: 2303-0178.

12. Batarseh, I.A and Ananzeh, N.E. (2015). The causal relationship among foreign direct investment, domestic saving and economic growth in Jordan during the period 19752013. International journal of business and management. 10(1). pp:73-79.

13. Belhadj. 2014. Employment measure in developing countries via minimum wage and poverty new fuzzy approach. OP Search. Volume 52 Nomor 2. 1-26.

14. Bozena, Kaderabkova, Jonathan Jasova. 2016. Character And Intensity Of The Minimum Wage Influence On Unemployment In The Czesh Republic And Slovakia. International Journal Of Economic Sciences. Vol. V, No. 1/2016.

15. BPS Provinsi Bali. 2020. Indeks Pembangunan Manusia Kabupaten/kota di Provinsi Bali 2015-2019. Denpasar: BPS Bali.

16. Brata, Aloysius Gunadi. 2005. Investasi Sektor Publik Lokal, Pembangunan Manusia, dan Kemiskinan. Lembaga Penelitian-Universitas Atma Jaya Yogyakarta, Februari.

17. Bernhard Boockmann, 2010, The Combined Employment Effects Of Minimum Wages 
And Labor Market Regulation. A Meta-Analysis. IZA Discussion Paper No. 4983.

18. Chalid, Nursiah dan Yusbar Yusuf. (2014). Pengaruh Tingkat Kemiskinan, Tingkat Pengangguran, Upah Minimum Kabupaten/Kota dan Laju Pertumbuhan Ekonomi terhadap Indeks Pembangunan Manusia di Provinsi Riau. Jurnal Ekonomi. 22(2). Halaman: 1-12.

19. Chinweoke, N., Ray, N., and Paschal, N. O. 2014. Impact of Government Expenditure on Nigeria's Economic Growth (1992-2011). The Macrotheme Review, 3(7), 79-87.

20. Dalamagas, Basil. 2010. Publik Sector and Economic Growth: The Greek Experience. Bulletin of Indonesian Economic Studies. 32(3). Hal:277-288.

21. Dewi, Novita. (2017). Pengaruh Kemiskinan dan Pertumbuhan Ekonomi terhadap Indeks Pembangunan Manusia di Provinsi Riau. Jurnal Online Mahasiswa Fakultas Ekonomi. 4(1). Halaman:870-882.

22. Dewi, Putu Ayu Krisna, dan I Ketut Sutrisna. 2014. Pengaruh Kemandirian Keuangan Daerah dan Pertumbuhan Ekonomi Terhadap Indeks Pembangunan Manusia di Provinsi Bali. E Jurnal EP Unud. 4(1): 32-40.

23. Ding, Hong. (2014). Economic growth and welfare state: A Dabate of econometrics. American research institute. International jurnal Vol. 2(2), pp, 165-196.

24. Edogbanya, Adejoh. 2013. Revenue Generation: Impact on Government Developmental Effort (A Study of Selected Local Council in Kogi East Senatorial District). Global Journal of Management and Business Research. 13(4). Hal: 12-26.

25. Ehrenberg, Ronald G. dan Smith, Roberth S. 2009. Modern Labor Economics: Theory and Public Policy. 10th Edition. United States: Pearson Education.

26. Eldy, Elifaz. Ari Pradhanawati dan Hari Susanta Nugraha. 2016. Pengaruh Upah, Peran Serikat Pekerja terhadap Kesejahteraan Pekerja nelalui Unjuk Rasa Pada Serikat Pekerja Nasional PSP PT Sai Apparel Industries. Jurnal Diponegoro. Program studi Administrasi Bisnis.

27. Fasoranti, Mary Modupe. 2012. The Effect of Government Expenditure on Infrastructure on the Growth of the Nigeria Economy, 1997-2009. International Journal of Economic and Financial Issues. 2(4). Hal: 513-518.

28. Feriyanto, Nur. 2020. The Impact of Unemployment, Minimum Wage, and Real Gross Regional Domestic Product on Poverty Reduction in Province of Indonesia. Journal of Asian Economic and Financial Review. Vol 10 No. 10 pp: 1088 - 1099.

29. Gindling. 2018. Does increasing the minimum wage reduce poverty in developing countries?. World of Labor. Volume 56 Issue 2. 313-331.

30. Gustyarini, Nur Indah Dwi. 2019. Analisis Faktor yang Mempengaruhi Kesejahteraan Masyarakat di Provinsi Jawa Tengah. Tesis. UNNES Repository

31. Herman. 2018. Pengaruh Upah Minimum Kota Terhadap Indeks Pembangunan Manusia Kota Pekanbaru (2009-2016). Riau Economics and Business Reviewe. Vol 9. No. 1.

32. Hugan, Gao. 2012. Co-integration Model of Logistic Infrastructure Investment and Regional Economic Growth in Central China. International Conference on Medical Physics and Biomedical Engineering. Volume:33, 2012, Pages:1036-1041.

33. Hukom, Alexandra. 2014. Hubungan Ketenagakerjaan Dan Perubahan Struktur Ekonomi terhadap Kesejahteraan Masyarakat. Jurnal Ekonomi Kuantitatif Terapan. Jurusan IImu Ekonomi, Fakultas Ekonomi Universitas Palangka Raya.

34. Irawan, Andi. 2015. Regional Income Disparities in Indonesia: Measurements, Convergence Process, and Decentralisation. Bull. of Ind. Econ. Studies, 51(1): 148-149.

35. Isa, Arham, \& Dai. 2019. Effects of Capital Expenditures, Development Index and Unemployment on Poverty in Gorontalo Province. JEJ. Volume 1 Issue 1. 1-10.

36. Kaur, Masjinder. 2016. Knowledge in the Economic Growth of Developing Economies. Bulletin of Indonesian Economic Studies. 8(2). Hal: 205-212.

37. Ka'arieni. 2020. An Analysis of Economic Performance on Community Welfare. KnE Social Sciences ICE-BEES 2019. Vol. 2020 pg: 1409 - 1421.

38. Kotambunan, Lavenia, Sutomo Wim Palar, dan Richard L.H Tumilaar. 2016. Analysis Effect Of Capital Expenditure And Human Development Index (Hdi) On Poverty In North Sulawesi (In Years 2005-2014). Jurnal Berkala Ilmiah. 16(1). Halaman: 925-933. 
39. Krismajaya, Putu; Martini Dewi, Ni Putu. 2019. Pengaruh Belanja Daerah dan Investasi Terhadap Kesejahteraan Masyarakat Melalui Pertumbuhan Ekonomi Pada Kabupaten/Kota Provinsi Bali. E-Jurnal Ekonomi Pembangunan Universitas Udayana.

40. Kunle, Adeleke, Olowe dan Oluwafolakemi. (2014). Impact of Foreign Direct Investment on Nigeria Economics Growth. Int. Journal of Academic Research. 4 (8), pp: 234-242.

41. Kurniawan Septyono, Sulistyaningrum Eny, 2017, Dampak Serikat Buruh Terhadap Tingkat Upah Buruh Sektor Swasta di Indonesia. Jurnal Ekonomi Kuantitatif Terapan. Vol. 10 No. 2:193-215.

42. Kusuma, Hendra. 2016. Desentralisasi Fiskal dan Pertumbuhan Ekonomi di Indonesia. Jurnal Ekonomi Kuantitatif Terapan, Vol. 9 No. 1. Halaman: 1-11.

43. Luthfiyah, Ukhti dan Amandus Jong Tallo. 2020. Analisis Ketimpangan Ekonomi Provvinsi Bali Tahun 2019. Jurnal IImu Pendidikan Nonformal. Vol. 6 No. 3: 241-248.

44. Mangkoesoebroto, Guritno. 2001. Ekonomi Publik. Yogyakarta: BPFE.

45. Mehrara, Mohsen, Mosayeb Pahlavani, and Yoursef Elyasi. 2011. Government Revenue and Government Expenditure Nexus in Asian Countries: Panel Cointegration and Causality. International Journal of Business and Social science. 2(7). Hal: 199-207.

46. Miranti, Riyana., Alan Duncan, and Rebecca Cassells. 2014. Revisiting the Impact of Consumption Growth and Inequality on Poverty in Indonesia during Decentralisation. Bulletin of Indonesian Economic Studie. 50(3). Hal: 461-482.

47. Mulia, Rizki Afri. 2020. Analisis Faktor-Faktor yang Mempengaruhi Kesejahteraan Masyarakat di Kota Padang. Jurnal El-Riyasah. Vol. 11 No. 1.

48. Nababan, T. S. 2017. The Effects of Number of Industrial EntelDRrses, Value of Input, Value of Output, and Regional Minimum Wage on Labor Demand in Indonesia: An Empirival Study on Micro Industrial EntelDRrises.

49. Nangarumba, Muara. 2015. Analisis Pengaruh Struktur Ekonomi, Upah Minimum Provinsi, Belanja Modal, dan Investasi Terhadap Ketimpangan Pendapatan di Seluruh Provinsi di Indonesia. JESP. Vol. 7. No. 2.

50. Nashahta Ardhiaty Nurfiat, Surya Dewi Rustariyuni. 2018. Pengaruh Upah dan Teknologi Terhadap Produktivitas dan Penyerapan Tenaga Kerja Pada Industri Mebel di Kota Denpasar. PIRAMIDA.Vol. XIV No. 1: 34-48.

51. Ndakularak, Erwin. 2014. Analisis Faktor-Faktor yang Mempengaruhi Kesejahteraan Masyarakat Kabupaten/Kota di Provinsi Bali. E-Jurnal Ekonomi dan Bisnis. Volume 3, No. 3, Tahun 2014.

52. Nehru, Vikram. 2013. Survey of Recent Developments. Bulletin of Indonesian Economic Studies, 49 (2), pp.139-166.

53. Nisa, An dan Herniwati Retno. 2021. Pengaruh Pertumbuhan Ekonomi, Investasi dan Belanja Modal Terhadap Kesejahteraan Masyarakat Di Jawa Tengah Tahun 2012-2018. Diponegoro Journal of Economics. Vol. 10. No.1.

54. Nworji, I. D., Okwu, A. T., Tomothy C, O., and Nworji. L. O. 2012. Effects of Publik Expenditure on Economic Growth in Nigeria: A Disaggregated Time Series Analysis. International Journal of Management Science and Business Research. 1(7). Hal: 1-15.

55. Pambudy, Priya Akhlis. 2019. Analisis Peran Belanja Modal dan Investasi Swasta Terhadap Pertumbuhan Ekonomi Serta Dampaknya Pada Kesejahteraan Masyarakat. EKOBIS. Vol. 20. No 1: 26-39.

56. Putra, Putu Indra Perdana dan I Putu Yadnya. 2018. Analisis Sektor Unggulan Perekonomian di Kabupaten/Kota Denpasar, Badung, Gianyar, dan Tabanan. E-Jurnal Manajemen Unud. Vol 7, No. 10:5657-5685.

57. Putri, V. K, dan Sasana, H. 2017. Pengaruh Faktor UMK, Belanja Pemerintah Daerah, Investasi Swasta, serta Inflasi terhadap PDRB dan Posisi Perekonomian Kabupaten/Kota Provinsi Jawa Tengah tahun 2010-2015. Fakultas Ekonomi.

58. Rahmawati, Ikka Dewi. 2015. Pengaruh Investasi dan Tingkat Upah terhadap Kesempatan Kerja di Provinsi Jawa Timur. E-Jurnal Ekonomi. Fakultas Ekonomi, Universitas Negeri Surabaya.

59. Ramirez, Penza, \& Mogenzen. 2015. The Effect of Minimum Wage on Poverty. Journal Georgia Institute of Technology. Volume 1 Issue 1. 1-20. 
60. Randy Tapparan, Samuel. 2017. Pengaruh Upah Minimum dan Investasi terhadap Kesempatan Kerja di Provinsi Sulawesi Selatan. Jurnal Pemikiran IImiah dan Pendidikan Administrasi Perkantoran. Vol. 4. No. 1.

61. Rustariyuni, Surya Dewi. 2012. Pengaruh Gini Ratio, Pengeluaran Non Makanan Per Kapita, Belanja Daerah Dan Laju Pertumbuhan Ekonomi Pada Indeks Pembangunan Manusia Kabupaten/Kota Di Provinsi Bali Periode 2004- 2012. PIRAMIDA.

62. Salih, Mohame Abdel Rahman. 2012. The Relationship between Economic Growth and Government Expenditure: Evidance from Sunda. Int. Business Research. 5(8). pp: 40-46.

63. Sari, Catur Nanda Puspita. 2020. Analisis Pengaruh Inflasi dan Investasi Terhadap Pertumbuhan Ekonomi dan Kesejahteraan Masyarakat di Pulau Jawa Tahun 2006-2016. Jurnal Ekuilibrium. [S.I.]. Vol.3, No.1: 46-60.

64. Setiawan, Gusi Bagus Kompiaang Putra. 2015. Pengaruh Pertumbuhan Ekonomi, Investasi, dan Belanja Modal Terhadap Kesejahteraan Masyarakat di Jawa Tengah Tahun 2012-2018. E-Jurnal EP Unud. 4[10]: 1276-1303.

65. Shavira, Shella Okky. 2021. Pengaruh Pertumbuhan Ekonomi, Upah Minimum, dan Tingkat Pengangguran terhadap Kesejahteraan Masyarakat di Jawa Timur Tahun 20142018. Bharanomics. Vol 1. No. 2: 93-103.

66. Simona Ferraro, Birgit Hanilane, Karsten Staehr, 2018, Minimum Wages And Employment Retention. A Microeconometric Study for Estonia. Baltic Journal Of Economics 2018. Vol. 18, No. 1: 51-67.

67. Sugiyono. 2014. Metode Penelitian Bisnis. Jakarta: PT. Gramedia Pustaka Utama.

68. Sukirno, Sadono. 2008. Teori Pengantar Makroekonomi. Jakarta; Raja Grafindo Persada.

69. 2010. Makro Ekonomi Teori Pengantar. Edisi Ketiga. Jakarta: PT Raja Grafindo Persada.

70. Sulistiawati, Rini. 2012. Pengaruh Upah Minimum terhadap Penyerapan Tenaga Kerja dan Kesejahteraan Masyarakat di Provinsi di Indonesia. J. Eksos. Vol. 8 No. 3: 195-211.

71. Suryahadi, Asep. 2020. Studi Kasus Pembangunan Inklusif: Belajar dari Bali. Smeru Research Institute.

72. Suwandi. (2016). The Influence of Economic Growth on Poverty, Investment, and Human Development Index in Fak, Fak District, West Papua Indonesia. IOSR Journal of Economics and Finance (IOSR-JEF). 7(3). Halaman: 69-72.

73. Syam, A. Y., Lisandri, Rizani, F., \& Oikawa, S. (2018). Influence of PAD and DAU on Economic Growth with Capital Expenditure as an Intervening Variable on Regency and Municipal Government in South Kalimantan Province. Journal Research and Analysis: Economy, 1(May), 1-9.

74. Todaro, Michael P, dan Smith, Stephen C. 2010. Pembangunan Ekonomi di Dunia Ketiga, Buku 1 dan 2 Edisi Kedelapan. Jakarta; Erlangga.

75. Utama, Suyana. 2012. Aplikasi Analisis Kuantitatif (Edisi Keenam). Diktat Kuliah Fakultas Ekonomi Universitas Udayana.

76. Utami, Desak Nyoman. 2019. Pengaruh PAD dan Belanja Modal Terhadap Pertumbuhan Ekonomi dan Kesejahteraan masyarakat di Provinsi Bali. E-Jurnal EP Unud. 8[10]: 21952225.

77. Vicente \& Aniceto. 2016. The Impact of Legal Minimum Wages on Employment, Income, and Poverty Incidence in the Philippines. Disscution Papper. Volume 63 Issue 2. 1-11.

78. Virginanda, Rindang Rahma. 2015. Analisis Pengaruh UMK Terhadap Jumlah Tenaga Kerja, Kesejahteraan dan Pertumbuhan Ekonomi. Economics Development Analysis Journal. 4[4]: 404-413.

79. Wannakrairoj, Wit. 2013. The Effect of Education and Experience on Wages: The Case Study of Thailand in 2012. Southeast Asian Journal of Economics, 1(1), pp. 27-48.

80. Widyasanti, Amalia Adininggar. 2020. Indeks Pembangunan Ekonomi Inklusif Provinsi Bali. Bappenas.

81. Yasa, I Komang Oka Artana dan Sudarsana Arka. 2015. Pengaruh Pertumbuhan Ekonomi dan Disparitas Pendapatan Antardaerah Terhadap Kesejahteraan Masyarakat Provinsi Bali. Jurnal Ekonomi Kuantitatif Terapan. 8(1): 63-71.

82. Zouhaier, H. (2015). Institution, Invesment and Economic Growth. International Journal of Economics and Finance, 4(2), 152-162. 